\title{
Chapter 3 \\ The Policy Implications of Licensing Standard Essential FRAND-Committed \\ Patents in Bundles
}

\author{
Anne Layne-Farrar and Michael Salinger
}

\section{Introduction}

The majority of standard development organizations (henceforth "SDOs") 1 around the globe have policy statements guiding member conduct to help ensure the smooth functioning of the standard setting process and the commercialization of standards after the technologies have been defined. The majority of SDOs with such policy statements include rules on the disclosure, use and licensing of patented technologies within the standards they develop, to help ensure that firms wanting to implement the SDO's standards will have access to the technologies required for standard compliance. By far, the most prevalent patent licensing rule calls for any patented technologies necessary for compliance with the standard-referred to as "essential" technologies - to be licensed on fair, reasonable, and non-discriminatory (henceforth "FRAND") terms and conditions. ${ }^{2}$ A great deal of ink has been spilled

We thank Koren Wong-Ervin for helpful comments.

\footnotetext{
${ }^{1}$ For example, among the 251 standards estimated to be included in a laptop, $75 \%$ are covered by FRAND licensing rules, while only $22 \%$ are covered by royalty-free licensing rules. See Brad Biddle et al., How Many Standards in a Laptop? (And Other Empirical Questions), ITU-T Kaleidoscope: Beyond the Internet?-Innovations for Future Networks and Services, at 1-7, IEEE (2010).

${ }^{2}$ Sometimes referred to as standard setting organizations, or SSOs.
}

\footnotetext{
A. Layne-Farrar $(\bowtie)$

Charles River Associates, Chicago, USA

e-mail: alayne-farrar@crai.com
}

A. Layne-Farrar

Northwestern University School of Law, Chicago, USA

M. Salinger

Boston University, Boston, USA

(C) The Author(s) 2018

A. Bharadwaj et al. (eds.), Complications and Quandaries in the ICT Sector,

https://doi.org/10.1007/978-981-10-6011-3_3 
on what a FRAND commitment does and does not imply, but until quite recently there was no analysis (to the best of our knowledge) of the implications of FRAND commitments for licensing patents in bundles or portfolios. ${ }^{3}$

The issue is an important one, since the norm in high technology industriesincluding mobile telecommunications, computer hardware, software, consumer electronics, and others - is for patent holders to license their patents at the technology portfolio level. That is, patent holders in high tech industries tend to license all of their patents on a given technology in a single bundled license agreement; it is rare to see an arm's length license agreement within such industries covering standard essential patents (henceforth "SEPs") only, without the inclusion of at least some non-FRAND-committed patents.

In this chapter, we address the relationship between the two common practices described above: FRAND commitments and patent portfolio licensing. More specifically, we discuss whether making a commitment to license patents on FRAND terms and conditions prevents a patent holder from licensing those patents only in a bundle with other non-FRAND-committed patents. Alternatively, we can ask whether a FRAND commitment necessarily obligates a patent holder to license its FRAND-committed patents on a stand-alone basis, without including any patents that lack such commitments in the license, should the licensee request such a limited license. If FRAND commitments do allow for portfolio licensing, the next question that arises is what that commitment might imply for the royalties charged for the whole portfolio.

To preview the findings upfront, economic analysis establishes that FRAND commitments do not prevent portfolio licensing. However, bundling FRANDcommitted patents with non-FRAND-committed patents does create a fundamental policy dilemma. On the one hand, a technology portfolio license can enable SEP holders to renege on a FRAND commitment. On the other hand, bundling patents is a widespread practice because it provides an efficient means of contracting that minimizes transaction and litigation costs for both licensors (the patent holders) and licensees (the manufacturers). Because of these efficiencies, it would be counterproductive to prohibit SEP holders from bundling patents into portfolio licenses, including both FRAND-encumbered and non-FRAND-encumbered patents. That being said, FRAND commitments do limit the license fees that a SEP holder can charge for a portfolio license. In fact, the FRAND royalty on a bundle of FRAND-committed and non-FRAND-committed patents can be less than what the FRAND commitment would be if the patent owner had made FRANDcommitments on all the patents in the bundle. More generally, economics establishes that even if a patent holder licenses its SEPs only in combination with other patents not bound by a FRAND commitment, such bundling is not a competitive problem per se, as long as the terms and conditions for the portfolio license are

\footnotetext{
${ }^{3}$ This chapter offers a non-technical summary and policy oriented extension of our theoretical paper on the antitrust implications of patent bundling, Anne Layne-Farrar \& Michael Salinger, Bundling of RAND-committed Patents, 45 RES. POL'Y (2016), available at http://www. sciencedirect.com/science/article/pii/S0048733316300269.
} 
consistent with the FRAND commitment for the SEP-only subset of the licensed portfolio. ${ }^{4}$ In other words, SEP holders may include non-FRAND-committed patents in a portfolio license agreement "for free." The economics of portfolio licensing then has further implications for licensees. Firms seeking a license cannot argue that a SEP-only license must be offered at a discounted price relative to the relevant portfolio license price; instead, licensees must establish that the portfolio license is priced higher than a SEP-only license would be before demanding a discount.

In the remainder of this chapter, we explain the above conclusions. Section 2 provides some important economic background, describing the key theories developed in the economics literature that underlie the analysis of patent bundling. Section 3 provides the discussion of the question of primary interest here: what does a FRAND commitment imply for bundled patent licensing. Section 4 concludes with the policy implications of our analysis.

\section{Important Economic Principles}

A key concept in the general economic literature on product bundling is the "single monopoly profit" theorem. ${ }^{5}$ Because this theorem applies more broadly than to just monopolists, we use the term "single rent" theorem here. This theorem, explained and summarized in Sect. 2.1, helps to distinguish when bundling has the potential to pose antitrust concerns.

In assessing the antitrust risks, it is important to understand how common bundling is throughout the economy and why that is the case. Section 2.2 therefore turns to the substantial and growing economics literature that investigates the causes of product bundling in general. One strand of that literature focuses on bundling intellectual property (such as computer software, music, and video entertainment).

\footnotetext{
${ }^{4}$ SDOs with FRAND commitments typically apply those commitments to the full terms and conditions of the license, and not solely to royalty rates or explicit financial payments. See for e.g., the European Telecommunications Standards Institute IP Policy, http://www.etsi.org/images/files/ ipr/etsi-ipr-policy.pdf. In the discussion here, for simplicity we focus on running royalty rate terms and assume that all other terms and conditions are held constant and in compliance with the FRAND commitment.

${ }^{5}$ While the term is widely recognized, we have not been able to document the source of the term. Whinston attributes the arguments to a Chicago oral tradition. Michael Whinston, Tying, Foreclosure, and Exclusion, 80 Am. Econ. Rev. $837-59$ (1990). Bowman recognizes the strong assumptions underlying the principle and a set of exceptions to it when those assumptions do not apply, see Ward S. Bowman, Tying Arrangements and the Leverage Problem, 67 YALE L. J., 19-36 (1957).

${ }^{6}$ Economists (as well as lawyers and courts) typically use the phrase "single monopoly profit," but we prefer the term "single rent" because the argument applies to rents of any kind, including patent royalties.
} 
The narrower topic of bundling patents in licenses, however, is quite sparse. ${ }^{7}$ One notable exception is a theoretical study by Gilbert and Katz ${ }^{8}$ who develop a model of patent bundling outside of standard setting contexts. Section 2.2 provides a review of this strand of the literature as well.

Layne-Farrar and Salinger ${ }^{9}$ extend the Gilbert and $\mathrm{Katz}^{10}$ model to incorporate standard setting contexts, FRAND commitments, and the combination of FRAND-committed and uncommitted patents in a single license. ${ }^{11}$ The discussion presented in Sect. 3 is based on the analysis developed in the Layne-Farrar and Salinger ${ }^{12}$ paper.

\subsection{The Single Rent Theorem}

When a seller practices "tying" or "pure bundling" it conditions the purchase of good A on the purchase of good B. In other words, in order to purchase A, the customer must also purchase B, whether or not the customer wants B. To those unfamiliar with economic reasoning, both the rationale for tying and the potential harm from it might seem obvious: the consumer is harmed because he pays for an item he does not want and the seller benefits because it gets the profits from selling the additional item. But that argument is incomplete for two reasons. First, it

\footnotetext{
${ }^{7}$ Patent bundling is related to but different from patent pooling, which Shapiro \& Lerner and Tirole have analyzed theoretically. Patent pooling entails licensing patents held by different patent owners in a single package. Patent bundling refers to licensing multiple patents held by a single patent-owner as a package. See Carl Shapiro, Navigating the Patent Thicket: Cross Licenses, Patent Pools, and Standard Setting in 1 InNovation Pol'y And The Econ., 119-150 (Adam Jaffe, Josh Lerner \& Scott Stern eds., 2001), http://www.nber.org/chapters/c10778.pdf; Josh Lerner \& Tirole Jean, Efficient Patent Pools, 94 Am. Econ. Rev., 691-711 (2004).

${ }^{8}$ Richard J. Gilbert, \& Michael L. Katz, Should good patents come in small packages? A welfare analysis of intellectual property bundling, 24 INT'L J. INDUS. ORG. 5, at 931-952, (2006).

${ }^{9}$ Layne-Farrar \& Salinger, supra note 3, at 1155-1164.

${ }^{10}$ Gilbert \& Katz, supra note 8.

${ }^{11}$ Note that, while most commonly made in the context of standard setting within SDOs, FRAND pledges are not limited to such cooperative efforts, in large part because SDOs are not the only way that technology standards emerge. The Program for Information Justice and Intellectual Property, at Washington College of Law, maintains a database of more than 150 such public non-SDO patent pledges: http://www.pijip.org/non-sdo-patent-commitments/. See Jorge Contreras, A Market Reliance Theory for FRAND Commitments and Other Patent Pledges, UtaH L. Rev., 479 (2015) and E. Elhauge, Treating RAND Commitments Neutrally, 11 J. Competition L. ANd Econ. 1, at 1-22 (2015), (For discussions of the legal basis for enforcing FRAND commitments made outside an SDO setting). For other discussions of non-SDO patent pledges, see Anne Layne-Farrar, Moving Past the SEP RAND Obsession: Some Thoughts on the Economic Implications of Unilateral Commitments and the Complexities of Patent Licensing, 21 GEORGE MASON L. Rev., 4, (2014) and J. Harkrider, REPs Not SEPs: A Reasonable and Non-Discriminatory Approach to Licensing Commitments, Antitrust Chronicle, 10 (2013).

${ }^{12}$ Layne-Farrar \& Salinger, supra note 3.
} 
presumes that the price the seller charges for the A-B bundle exceeds what it would have charged for A sold separately by more than the incremental cost of adding B to the product bundle. Second, it also presumes that tying A and B together does not reduce demand for good A (which would drive the seller's profits down). If both assumptions were true, then tying B to A would increase the seller's profits, but these assumptions do not necessarily hold due to a principle known as the "single monopoly profit" theorem, or more accurately the "single rent" theorem.

One of the founding fathers of the theory, Judge Robert Bork, along with a co-author, explain in a fairly recent publication $^{13}$ :

The single-monopoly-profit theorem shows that, in a vertical chain of production, the vertically integrated monopolist can earn monopoly profit only in one of the marketseither the upstream or downstream market, but not both. Different stages in the vertical process are complements to one another. If retailers increase the markup on a particular product, the manufacturer's profits will fall. Likewise, when a manufacturer increases the wholesale price of a product, the retailers' profits will fall. ... In horizontal applications, the single-monopoly-profit theorem implies that firms typically cannot extend monopoly power over one product to other products without sacrificing total profit.

Judge Bork led the Chicago School of thought in developing the theory starting in the 1970s. ${ }^{14}$ The production of nuts and bolts offers the seminal horizontal market example. Suppose that the cost of making either a nut or a bolt is 10 cents each. Assume that the market for bolts is competitive, meaning the price of a bolt is set at its marginal cost of 10 cents, while a monopolist controls the production of nuts. Could the nut maker extend its nut monopoly to bolts through product tying, as a means of increasing its monopoly profits and foreclosing competitors in the bolt market? Suppose that the monopolistic price for a nut-bolt combination is 40 cents. Since the bolt market is competitive, all manufacturers will charge the marginal cost of 10 cents for a bolt while the monopolist will charge 30 cents for a nut, enabling the nut monopolist to reach the 40 cent price target and earn 20 cents in profits. If the nut maker ties nuts and bolts together, it would set the price of the bundle at 40 cents, again earning 20 cents in profits. In summary, the monopolist cannot increase its profits through tying the two products together; there is but a single rent to be earned regardless of whether the products are tied or sold separately.

The single rent principle is a key underpinning for the so-called Chicago critique of a wide range of antitrust policies, including tying. Beginning in the 1940s,

\footnotetext{
${ }^{13}$ Robert H. Bork \& J. Gregory Sidak, What Does the Chicago School Teach About Internet Search and the Antitrust Treatment of Google?, 8 J. CoMPETITION L. \& Econ., 4 at 663-700 (2012). For Bork's original work on the subject, see Robert A. Bork, The Antitrust Paradox: A Policy Аt War With Itself, at 372-75, 380-81 (2d ed. 1993).

${ }^{14}$ See, for example, Richard A. Posner, The Chicago School of antitrust analysis, 127.4, U. OF PA. L. Rev., at 925-948 (1979); Richard a . Posner \& Frank H. Easterbrook, Antitrust: Cases: Economic Notes And Other Materials. (1981); Benjamin Klein, "Tying”, The New Palgrave Dictionary Of Economics And The Law, at 630-631 (Peter Newman ed., 1998); and Richard A. Posner, ANTitrust Law at 197-99 (2d ed., 2001).
} 
antitrust policy makers have expressed concerns that a firm with market power in one market could "leverage" that power into adjacent markets by tying the sale of the good with market power to the purchase of some other good. ${ }^{15}$ The Chicago School - a group of legal and economic scholars associated with The University of Chicago - challenged this view, largely on the basis of the single rent theorem. They argued that this principle cast serious doubts on claims that firms' incentives to tie goods together were rooted in "leveraging" or anticompetitive "foreclosure." If firms with market power could only earn a single profit from a combination of goods, then another explanation must be found for the prevalent practice of product tying and bundling.

The single rent theory, like all economic theories, rests on some key assumptions, however.

Most importantly, the products must be strong complements to one another and they must be used in fixed proportions. If nuts and bolts were used in varying proportions, say because some applications called for a bolt but did not require a nut, the single rent theorem would not hold, and tying the purchase of nuts and bolts together could potentially increase the seller's profits. The first question to ask when assessing the potential of anticompetitive tying is therefore whether or not the single rent theorem assumptions hold in the circumstances at hand.

To see more clearly how the single rent principle works, and when it might fail, consider another simple example. Suppose that a restaurant chain plans to sell one kind of drink at each of its locations, the "Half-and-Half", which requires a mixture of lemonade and brewed tea. ${ }^{16}$ The traditional proportions of the two mandatory (i.e., perfectly complementary) ingredients is 50/50. Further suppose that the restaurant drink supplier incurs costs of $\$ 0.25$ per serving for lemonade and $\$ 0.10$ per serving for brewed tea. The going retail price for a glass of Half-and-Half is $\$ 5.00$ and the restaurant chain is targeting a $\$ 4.00$ profit margin per serving. Thus, the profit maximizing price that the drink supplier can charge for the two Half-and-Half ingredients combined is $\$ 1.00$ per serving, ${ }^{17}$ yielding a profit to the supplier of $\$ 0.65$ per serving $(\$ 1.00-\$ 0.10-\$ 0.25)$. In this case, the supplier could charge $\$ 1.00$ for the bundle of ingredients, $\$ 0.50$ per ingredient for a sum of $\$ 1.00$ per serving, or some other split between the two inputs that sums to $\$ 1.00$ per serving. Alternatively, the supplier could sell the tea to the restaurant for $\$ 1.00$ per serving and "throw in" the lemonade "for free." For the restaurant chain selling only Half-and-Half drinks mixed at 50/50, any of these options would be equally acceptable (i.e., equally profitable) and the supplier would earn the same $\$ 0.65$ profit per serving under any of the pricing alternatives. It is this logic that led the

\footnotetext{
${ }^{15}$ For a review of the history of the monopoly leverage theory, see Jennifer M. Clarke-Smith, The Development of the Monopolistic Leveraging Theory and Its Appropriate Role in Antitrust Law, 52 Cath. U. L. Rev. (2002).

${ }^{16}$ This is a drink comprised of half lemonade and half tea, made popular in the United States by the golfer Arnold Palmer.

${ }^{17}$ The implicit assumption here is that the restaurant chain has an outside option (say, soft drinks), so that it has bargaining power over its desired margin.
} 
Chicago School to conclude that when the single rent principle holds, efficiency reasons are the most likely motivation for product tying and bundling (a point discussed further below).

But what happens when we drop the key assumption of fixed proportions? Suppose the drink supplier has a monopoly over lemonade and therefore charges the monopoly price for lemonade at $\$ 1.00$ per serving, while a competitive market supplies tea at $\$ 0.10$ per serving. The restaurant will substitute toward tea by mixing its Half-and-Half drinks with a higher proportion of tea than lemonade. A drink supplier with market power in both lemonade and tea, however could tie the sale of the two products to eliminate such substitution. For a restaurant chain with no other drink supply options, the tied sale would push more lemonade on the restaurant than it demands-and would increase the supplier's profits at the restaurant's expense as compared to selling the two drink ingredients separately. This example makes clear that market power is still a prerequisite for anticompetitive harm: if the restaurant has an alternative lemonade supplier, a single supplier attempting to tie tea and lemonade will be unsuccessful. When that prerequisite is met, breaking the assumption of fixed proportions for complementary inputs breaks the single rent principle and creates anticompetitive incentives for tying.

In extending the single rent analysis to patents, it is important to keep the market power condition in mind. A patent is a property right that does not by itself confer a monopoly any more than other forms of asset ownership do. By way of analogy, an apartment building is also a property right that might appear to give the owner a "monopoly" over the rental of apartments in that particular building. But the fact that there is a single seller of a specific asset does not constitute a monopoly unless that asset constitutes a well-defined market. If other apartment buildings (or other forms of housing) are competitive alternatives to the apartments in a particular building, the owner of the building has a property right but not a monopoly. Patented technologies are similar. While some patents might well constitute well-defined markets, not all patents do, and in practice most patents do not.

This is true of SEPs as well. First, such patents are self-declared to SDOs. The patent holder is asked to exercise good faith in identifying the patents it believes may be (or may become) essential for technical compliance with a given standard, but no SDO evaluates the declared patents to determine whether they are in fact essential. Furthermore, as the standard continues through development, which patents are and are not essential for its practice tend to change. Until an independent review (legal and technical) establishes that a particular declared patent is in fact essential for the practice of a standard, there can be no presumption of market power. ${ }^{18}$ Second, and equally important, even restricting the analysis to truly essential patents for a particular standard, we cannot automatically conclude that an individual SEP or portfolio of SEPs held by a single patent holder constitutes a

\footnotetext{
${ }^{18}$ Typically, an essentiality determination is conducted only when necessary, such as if the patent is submitted for inclusion in a patent licensing pool or when the patent is litigated.
} 
well-defined market and that ownership confers market power. SEPs are perfect complements to one another. This creates a connection among the patents that in turn imposes a connection among the patent holders. As a result, SEPs cannot be licensed in isolation. Specifically, royalty rates consistent with FRAND are tied to the value the patented technologies contribute to the standard, which inherently accounts for all valuable contributions to the standard (i.e., the value contributed by all other SEPs). In contrast to monopolists, who can set prices without consideration of other firms, SEP holders must take into account the value of other SEPs when setting their own royalty rates. Reinforcing this dynamic, firms taking a license to SEPs know they must license all SEPs to be compliant with the standard. As a result, licensees push back in negotiations if they feel an SEP holder is attempting to ask for more than its share. All of these factors lessen any market power that might be conferred by essentiality. The degree to which market power is mitigated by complementarities is an empirical matter and thus market power for SEPs, just as for non-SEPs, should be evaluated on a case-by-case basis.

\subsection{The Economic Literature on Bundling}

With the bounds of the single rent theorem in mind, we turn next to the extensive literature on tying and bundling. This entire literature is about exceptions to the single rent principle. The first strand focuses on how tying can be used to practice price discrimination. ${ }^{19}$ The second strand focuses on the circumstances under which tying can be used to foreclose rivals (leverage market power). The first two subparts below review these strands of the literature.

The emphasis in the literature on the exceptions should not obscure the general rule, however.

The intuition that the objective of tying is to leverage market power from one good to another often fails to withstand rigorous economic scrutiny. Thus, other, non-anticompetitive rationales are needed to explain the very common practice of tying and bundling. The third subpart below discusses the literature that establishes this point. Finally, the fourth subpart discusses the two papers that address the tying and bundling of patents; specifically, Gilbert and $\mathrm{Katz}^{20}$ and Layne-Farrar and Salinger. ${ }^{21}$

\footnotetext{
${ }^{19}$ Price discrimination is not necessarily harmful to consumers. Economists only condemn price discrimination that leads to output reductions. See Lars A. Stole, Price Discrimination and Competition, in 3 Handbook of Industrial Organization at 2223 (2007).

${ }^{20}$ Supra, note 8.

${ }^{21}$ Supra, note 3 .
} 


\section{Price discrimination}

The "price discrimination" strand of the literature on bundling started with George Stigler's analysis of block booking practices for cinemas. ${ }^{22}$ The argument rested on a simple example. A firm sells two products, A and B, to two customers, I and II. In Stigler's article, the seller is a movie distributor, the products are films, and the customers are movie theaters. Customer I is willing to pay $\$ 10$ for movie A and \$2 for movie B. Customer II is willing to pay $\$ 2$ for movie A and $\$ 11$ for movie B. If the seller does not bundle, it will charge \$10 for movie A and \$11 for movie B. Only customer I will buy movie A. To get customer II to buy movie A also, the seller would have to lower its price to $\$ 2$, but selling two units at a price of $\$ 2$ generates less profit than selling one unit at price of $\$ 10$ (even assuming that marginal cost is 0 ). Similarly, at a price of $\$ 11$, only customer II will buy movie B. Stigler's insight was that the movie distributor could offer the two products solely in a bundle and charge each customer $\$ 12$. Both customers would then buy both products. In this example, bundling is "Pareto superior"- - meaning that no party is harmed and some receive a positive benefit-as compared to selling the goods separately.

That is, under this example bundling enables the seller to earn a profit of \$24 instead of $\$ 21$ and consumer surplus goes up as well (from 0 to $\$ 1$ ). ${ }^{23}$

While much of the subsequent literature has focused on extending the Stigler model to more general circumstances, arguably the most important extension for tying policy to emerge from this follow-on literature is due to an early contribution by Adams and Yellen. ${ }^{24}$ Like Stigler's model, their analysis was based on assumptions about the willingness to pay among a discrete number of customers. Adams and Yellen pointed out that mixed bundling yields higher profits for price discrimination than pure bundling does. Pure bundling means that the firm sells only the bundle; the individual products cannot be purchased separately. Mixed bundling means that the firm offers customers a choice of the bundle or the separate, individual goods, with the price of the bundle being different (typically less than) the sum of the individual prices. In the context of the Stigler model, pure bundling would occur if the movie distributor only offered the A and B movies together for a price of $\$ 12$, while mixed bundling would occur if the movie distributor offered

\footnotetext{
${ }^{22}$ See G. J. Stigler, United States v. Loew's Inc.: A note on block-booking, SuP. Cт. REV., at 152-157 (1963).

${ }^{23}$ The single rent principle does not apply in the Stigler setting because the monopolist has two monopolies rather than one. Moreover, the model rules out price discrimination in selling the goods separately. As a result, simple pricing of the two goods leaves a "deadweight loss." Customer A values good II at more than marginal cost but less than the simple monopoly price. The same point applies to customer B and good I. Thus, the bundling in this example does not force on each customer a good that he values at less than marginal cost. The standard interpretation of the Stigler model is that bundling is a substitute for price discrimination.

${ }^{24} \mathrm{~W}$. J. Adams \& J. L. Yellen, Commodity bundling and the burden of monopoly, THE Q. J. OF Econ., at 475-498 (1976).
} 
three distinct packages: the two- movie bundle at $\$ 12$, or movie $\mathrm{A}$ alone for $\$ 10$ and movie B alone for $\$ 11$.

Adams' and Yellen's insight on mixed bundling is important for competition policy because mixed bundling is not the same as pure bundling or tying. Under mixed bundling, customers have even more choices and are free to obtain the individual goods should they so desire. ${ }^{25}$ It is only pure bundling that restricts customer choice and has the potential to create harm. While important for understanding certain seller motivations in combining goods into bundles, the price discrimination strand of the literature is insufficient to explain why firms would ever choose not to offer the individual goods separately as well. ${ }^{26}$

\section{Foreclosure}

The foreclosure strand of the literature developed formal economic models to clarify when tying should raise antitrust concerns, particularly as to when it might work as a form of monopoly leveraging.

Whinston $(1990)^{27}$ is the seminal paper in this area. He analyzed the possible strategies for a firm that initially has a monopoly over two products. Its position in one $(\operatorname{good} A)$ is protected but it faces potential entry with respect to the other (good B). In Whinston's model, tying B to A offers the seller a means to commit to price aggressively in response to a rival's entry into B. By refusing to sell A without B, the incumbent lowers the profits it can earn if entry into the B market does occur: losing sales of B after a rival enters not only reduces the incumbent's profits from sales of B but also reduces its profits from sales of A. With tying, a lost B sale also means a lost $\mathrm{A}$ sale, so tying gives the incumbent an extra incentive to price more aggressively in the face of potential entry than it otherwise would have done.

An essential element of the Whinston model is the assumption of economies of scale in the production of good B. Thus, even if the incumbent continues to price good A above its marginal cost (to avoid prohibitions against predatory pricing), the lower price for the A-B bundle as compared to pricing for the two goods separately

\footnotetext{
${ }^{25}$ The distinction between pure bundling and mixed bundling can be blurry when the price of the bundle is so close to the price of the individual goods that the seller engages in what is called a "virtual tie".

${ }^{26}$ Much of the subsequent price discrimination strand of the literature extends the Stigler and Adams-Yellin analysis to more general distributions with notable contributions by Schmalensee and McAfee, McMillan, and Whinston. McAfee, McMillan and Whinston show that for completely general continuous distributions of reservation values, mixed bundling almost always yields higher profits for the seller than pure bundling. It is possible that the optimal mixed bundle might entail charging a premium for the bundle, which would only be a practical policy if the seller can prevent those who want both goods from buying them separately. See Richard Schmalensee, Gaussian demand and commodity bundling, THE J. OF Bus., at S211-S230 (1984) and R. P. McAfee et al., Multiproduct monopoly, commodity bundling, and correlation of values $104 \mathrm{THE}$ Q. J. of Econ. 2, at 371-383 (1989).

However, we are not aware of anyone who has seriously suggested that tying can occur because it is not feasible to charge a premium for the bundle.

${ }^{27}$ Whinston, supra note 5 , at 837-59.
} 
can still render entry by a new rival into the B market unprofitable because the rival cannot achieve sufficient scale to compete effectively against the incumbent.

In game-theoretic analysis, commitment to a strategy means sticking with it even when it would be profitable to change course. In the Whinston model, the incumbent would like to sell A separately (at the monopoly price) after rival entry occurs in B if it could. However, as is often the case in game theoretic results, committing not to act in one's own short term interest can have a long term strategic value. When the incumbent commits not to act in its own interest by selling $\mathrm{A}$ separately, the new B entrant cannot exploit the incumbent's incentive to accommodate entry by unbundling the sale of the two goods, which in turn helps to prevent entry into the B market.

When the United States Department of Justice sued Microsoft for tying its browser to its Windows operating system, Carlton and Waldman ${ }^{28}$ adapted the basic Whinston model to assumptions that more nearly matched the facts of that case. Others have pursued different extensions. Of them, Choi and Stefanadis ${ }^{29}$ is of particular note. In their model, an incumbent monopolist sells two products (A and B) that consumers combine in fixed proportions. Entry into both product markets is possible, but both require investing in research and development (R\&D) and the outcome of that $\mathrm{R} \& \mathrm{D}$ is uncertain. Because the two goods are only useful in combination (such as a computer and an operating system software program), a firm that successfully innovates in A can only sell its product if consumers can purchase B also, so innovation in B must be successful. Alternatively, consumers might buy A from a successful entrant if they can combine it with B from the incumbent. If the incumbent sells A and B only in bundled form, it denies this one-good-at-a-time path to market entry. With higher costs of market entry and a reduced prospect for success, potential innovators might choose not to attempt entry at all. If entry into B also entails scale economies, then reduced access to potential customers (those who get $\mathrm{B}$ from the incumbent in order to get A) can tilt the balance in the entry decision and convince the potential entrant to stay out of the market altogether.

However plausible the foreclosure effect might seem as a matter of theory, it is important to critically assess claims that the theory applies in any particular instance. One must always pose the question, "Why does the seller of A refuse to sell it on a stand-alone basis to people who want to buy it but not buy B?" In the foreclosure literature, the answer to the question is that the seller generally does have an incentive to sell its monopolized good separately but foregoes that option for strategic reasons. ${ }^{30}$ The monopolists in the leveraging literature are imposing on

\footnotetext{
${ }^{28}$ Dennis W. Carlton, \& Michael Waldman, The Strategic Use of Tying to Preserve and Create Market Power in Evolving Industries, 33 RAND J. Econ, 194, at 195 (2002).

${ }^{29}$ Jay Pil Choi \& Stefanadis Christodoulos, Tying, Investment, and the Dynamic Leverage Theory, 32 RAND J. OF ECON., at 52-71 (2001).

${ }^{30}$ The model in Nalebuff is similar to Choi and Stefanadis in that the incumbent initially has a monopoly over two goods and faces random entry in both. Nalebuff argues that in addition to its entry-deterring effects, bundling increases profits relative to selling the goods separately and therefore is not costly. The argument draws on the price discrimination strand of the literature. But
} 
themselves the cost of not selling the good separately; they do so to influence the actions of potential entrants. In any real case, there needs to be a presumption that the commitment not to sell goods separately imposes a cost on the firm accused of tying to exclude competitors. To apply the argument in a specific case, one would have to present compelling evidence that the commitment to maintain tying is credible and that the benefit the seller receives from the tying commitment exceeds the cost that commitment imposes.

\section{Product complexity}

As explained above, any allegation about anticompetitive effects from tying must include a compelling answer to the following question: "If a firm is selling A only in combination with $\mathrm{B}$, why does the firm refuse to sell $\mathrm{A}$ on a stand-alone basis to people who want just A?"

It is impossible to overstate how common a phenomenon it is to bundle goods into packages. Many times every day people buy bundles of goods that include components they do not want. Shoes come with shoe laces. Newspapers come with an array of sections attached to the front page, from sports to the arts. Whenever the purchase of something includes something else "at no extra charge," the term "no extra charge" is code for "tied." The thirteenth item in a "baker's dozen" is not free. The baker who purports to be setting the price of a "dozen" knows very well that he is setting the price for 13 with the thirteenth item tied to the first 12. Ironically, the advent of separate baggage charges on airlines has engendered complaints, and Southwest Airlines has engaged in an extensive advertising campaign to tout its business practice of tying the right to check two pieces of luggage to its passenger flight service (although it of course does not explain its policy in these terms.)

Given that tying and bundling occur regularly in both highly competitive markets (bakeries) and less competitive ones (cable television programming), it is clear that the explanation for the practice has to be simpler than the leveraging and price discrimination models that dominated the economics literature through the early 2000s. Evans and Salinger ${ }^{31}$ provide such an explanation. They point to the cost of product offering complexity as the most natural explanation for tying and bundling. Firms face a long list of decisions even after deciding on their general line of business, including the exact features and components they will include in each product. Dell offers a good example. Rather than presetting a handful of computer models each with a specific screen size, hard drive capacity, memory, and operating system (among other features), Dell allows its customers to customize their

(Footnote 30 continued)

that argument ignores the possibility of mixed bundling, which would be even more profitable than pure bundling. See Barry Nalebuff, Bundling as a Barrier to Entry, 119 Q. J. OF Econ., at 159-187 (2004) and Choi \& Stefanadis, supra note 29.

${ }^{31}$ See David S. Evans \& Michael A. Salinger, Why do firms bundle and tie-evidence from competitive markets and implications for tying law, 22 Y ALE J. ON REG, at 37 (2005), and David S. Evans \& Michael A. Salinger, The Role of Cost in Determining when Firms Offer Bundles and Ties, 56 J. of Ind. ECON., at 143-168 (2008). 
computers by selecting from menus for each of these features. But even Dell does not include every conceivable configuration, and it is important to remember that Dell and the personal computer industry define the exception, not the rule, in product offering flexibility. In general, companies do not customize their offerings to the precise desires of every customer-it is typically not cost-effective or even feasible to do so.

Product offering complexity and cost provides an intuitively appealing explanation for the widespread practice of bundling. This explanation is well supported by the available evidence, such as the accounting literature on "activity-based costing." 32 Evans and Salinger provide evidence in their study comparing how United States and Japanese automobile companies offered optional features, like air conditioning, and how the relative practices of features changed over time. ${ }^{33}$ The most compelling evidence, however, is not published: it is the common experience of consumers who daily purchase bundles of items that are not available separately for sale.

\section{Patent bundling}

Patents, as intangible assets, are unlike traditional goods in a number of important ways, so while some lessons can be drawn from the existing bundling literature summarized above, that literature cannot be applied directly to patent licensing. In particular, unlike physical goods, there is typically no marginal cost to including an additional patent in a license bundle. The creation of claim charts linking the patented innovations to licensed products and services imposes additional costs during negotiations, but such charts are typically prepared only for the handful of representative patents driving the valuation exercise and are not required for each and every patent included in a portfolio license. ${ }^{34}$ From the licensee's perspective, there is also no inventory or disposal costs associated with an additional patent's

\footnotetext{
${ }^{32}$ See, e.g., Robin Cooper \& Robert S. Kaplan, Measure costs right: make the right decisions, 66 Harv. Bus. Rev., 5, at 96-103 (1988).

${ }^{33}$ When Japanese automobile companies first started their substantial penetration into the United States markets, each model came with only a small number - possibly only two - bundles of options. The Honda Accord might, for example, have a base model that did not have air conditioning or any sound system other than an FM radio, a middle model that included air conditioning, power windows, and a few more extra features, and a top model that also included leather seats, an upgraded sound system, a moon roof, and better tires. The original rationale was that the Japanese companies had longer supply lines and did not have the ability to supply cars with exactly the features customers wanted (to the relevant location). In contrast, US automobile companies were selling options on an a la carte basis. In some cases, even the AM/FM radio was effectively optional. (Ford listed it as standard, but a buyer could get a credit for not having it.) Over time, one might have expected competition to compel Japanese companies to adopt policies more like the US policy. To the contrary, the US car companies came to recognize that there were hidden costs to their more complex set of offerings and started emulating the Japanese companies by offering options only on a bundled basis. Thus, the tying strategy won out over the unbundling strategy in market competition.

${ }^{34}$ It is important to understand that fair and reasonable license fees for a portfolio of patents are not determined by adding up the value of each patent included. Instead, portfolio licensing exhibits
} 
inclusion in a license, as compared to unwanted physical goods tied to a wanted good; the addition of an "unwanted" patent in a portfolio license can simply be ignored.

The unique attributes of intangible goods alter bundling analysis in meaningful ways. The underlying economics in addressing the concerns with patent tying are largely the same as for physical good ties-analyzing whether the single rent theorem applies, and if not, whether bundling can create harm to competition-but patent tying adds a layer of complexity to the analysis because there are two levels of rents to consider: the ex ante rents that can be earned before a licensee makes any sunk investment (such as investments to commercialize a standard in a new product) and the ex post rents that can be earned after such investments are made (which could include expropriation of the licensee's sunk investments, known as "patent holdup"). ${ }^{35}$

Gilbert and $\mathrm{Katz}^{36}$ extend the bundling literature to patent licensing in light of differences between patents and physical goods. They developed a simple model to aid their analysis. The patent holder owns two patents on complementary technologies, so that value is earned from the technologies only when they are used in combination. The patent holder has no manufacturing capacity, so in order to earn a return on its patents, it must license them. A single licensee (the "manufacturer") comprises the downstream market. Assume for now that the manufacturer has no innovative capabilities. Thus, in order to produce a product to sell in the marketplace, the manufacturer must license the patents from the patent holder. In addition to taking a license, the manufacturer also must make a complementary investment to commercialize the patented technology. If the manufacturer does not obtain a license to the technology prior to investing in complementary commercialization assets then the patent owner may be able to practice holdup.

To put these issues in more concrete terms, we replicate here a numeric example based on the Gilbert and Katz model from our technical paper. ${ }^{37}$ Suppose that without any investment by the manufacturer, the patented technology yields a value of \$20 (unrealizable by the patent holder without licensing, by assumption). With efficient investment in complementary assets by the manufacturer, the technology embodied in an end product yields gross benefits (i.e., before taking account of the commercialization cost incurred by the manufacturer) of $\$ 100$ (unrealizable by the manufacturer absent the initial contribution by the patent holder). Call these gross benefits $\mathrm{B}$. The commercialization investment (refer to this amount as $\mathrm{S}$ ) has a cost

(Footnote 34 continued)

strong nonlinearities. For example, a license to 100 patents may set the fee at "L," while a license to those 100 plus another 20 more may still be licensed at "L".

${ }^{35}$ This analysis starts from the point in time that the patent holder has already made its $R \& D$ investment and has a patent in hand. Thus, in our discussion here "ex ante" refers to the licensee's investment, not the patent holder's.

${ }^{36}$ Supra, note 8 .

${ }^{37}$ Layne-Farrar \& Salinger, supra note 3. 
of $\$ 30$, so the potential net value of the patented technology embodied in the end product (patent plus manufacture) is $\$ 70$ (or $\mathrm{B}-\mathrm{S}=\$ 100-\$ 30$ ).

Knowing the above costs and benefits, the manufacturer would not invest $\mathrm{S}$ in complementary assets without first obtaining a license for the patented technology (ex ante, or long term contracting in Gilbert and Katz's terminology). At this time, the IP owner can charge no more than $\mathrm{B}-\mathrm{S}$ for the two patents (here $\$ 100-\$ 30=\$ 70$ ), which allows the manufacturer to make and recover its investment (and also to choose the most efficient level of complementary investment). If the manufacturer failed to obtain a license before making its commercialization investment, however, the IP owner could insist on a license fee $L=\$ 100$ (or just below it). With such ex post licensing (or short term contracting in Gilbert and Katz's terminology) the manufacturer would rationally accept this offer as it would be the manufacturer's best option at that point. In short, the presence of a sunk investment in commercialization is the key factor enabling holdup.

How does patent bundling enter into the picture? Up to this point, whether the technology is based on one patent or two is irrelevant - the manufacturer needs both. Thus, whether the IP owner offers the two patents separately or in a bundle is also irrelevant. It can offer to license the patents as a bundle at a license fee of $\$ 70$ or à la carte with individual prices that add to a cumulative fee of $\$ 70$.

Profits and consumer welfare (and, therefore, total surplus) are all the same under the various options for charging a total of $\$ 70$. The irrelevance of bundling under these conditions is an application of the single rent principle. One patent that is essential for a product gives the patent holder the ability to extract the same total license fee as it can with two such patents.

To this foundational model, Gilbert and Katz then adds the possibility that the manufacturer could invest in $\mathrm{R} \& \mathrm{D}$ to invent around the patented technology. If successful, the manufacturer would no longer need a license from the patent holder and the patent holder would earn zero profits. This setup addresses the antitrust concern that tying in patent licensing could reduce incentives of others in the industry (the manufacturer in the model) to innovate, particularly in terms of investments in non-infringing alternatives to the patented technology.

Ex ante contracting is a preferable licensing approach from a social perspective because it eliminates the potential for patent holdup. ${ }^{38}$ But in the Gilbert and Katz model, patent holders will only offer an ex ante license if allowed to offer bundled licenses. Thus, to obtain a license to a single patent, the licensee would have to wait for an ex post, short term contract. This setup introduces a competition policy tradeoff: ex ante licensing is efficient (inducing appropriate commercialization investments by manufacturers) but because the license is for the full technology portfolio, it will also reduce the manufacturer's incentive to invest in workaround technologies. On the other hand, ex post licensing may maintain the manufacturer's incentives to invest in $\mathrm{R} \& \mathrm{D}$ on alternative technologies, but also exposes the

\footnotetext{
${ }^{38}$ In the real world, a number of obstacles often prevent such licensing, particularly in standard setting contexts.
} 
licensee to the risk of patent holdup. Whenever the potential licensee is unsuccessful in developing workarounds for all of the needed patented technologies, the patent holder would be able to holdup the licensee using the remaining patents. Gilbert and Katz therefore conclude that (ex ante) bundled licensing is the welfare maximizing option. ${ }^{39}$

Combining the insights from Gilbert and Katz with the product complexity teachings of the Evans and Salinger papers discussed above provides strong justification for portfolio licensing, at least outside of standard setting contexts.

Some large technology companies hold tens of thousands of patents. Requiring them to license each one of those patents on an à la cart basis would impose a heavy cost burden on innovative firms: for a company with 1,000 patents (a relatively modest patent portfolio size), the number of possible combinations of patents for licensing is roughly $10^{301} .{ }^{40}$ Put differently, obligating a licensor with 1,000 patents in a given portfolio to unbundle any arbitrary combination of those patents would mean that the licensor would have to determine as many as one googol cubed different licensing prices and then monitor and enforce compliance for all those different licensing configurations. ${ }^{41}$ Clearly, just as with traditional product complexity, there is a cost of having more complex patent license offerings as well. Not surprisingly, in practice patent licensors offer a small subset of the patent bundles that they could conceivably offer. But even if many licensees only use a subset of the patents they license, the realities of product complexity and the efficiencies of portfolio licensing allay public policy concerns.

In our experience, most licensees (outside of litigation contexts, where incentives can be distorted for a number of reasons) prefer to license bundles of patents. Patent licenses help to disseminate technology and to reduce patent infringement litigation. If a company licenses only a subset of a licensor's patents that it needs to implement a technology in a given product, that licensee risks a patent-infringement lawsuit every time it modifies that product or introduces a new and improved version of that product - even if it pays the royalties due on the patents it does license. To protect against this scenario and to provide freedom in product design, licensees often request licenses to broad, inclusive patent bundles. ${ }^{42}$

Interpreting the Gilbert and Katz ex ante license as analogous to a FRAND commitment (namely, ex ante licensing to preclude patent holdup) clarifies why it is not anticompetitive to tie the license of one SEP to another SEP for the same standard. Within the same standard, all genuinely essential patents are perfect complements to one another and are used in fixed proportions (one license to each SEP is required). As a result, the assumptions for the single rent theorem hold and

\footnotetext{
${ }^{39}$ Observe that they also assume that all investments in workaround technologies are redundant, not contributing any new innovations. Dropping that assumption would complicate the analysis considerably.

${ }^{40}$ The math problem here is determining the combinatorial for 1,000 patents, where the patents can be taken by ones, or in combinations of twos, threes, or any other subset.

${ }^{41} \mathrm{~A}$ googol is equal to 10 raised to the $10^{\text {th }}$ power.

${ }^{42}$ This practice is common and is referred to as "freedom to operate" or "convenience" licensing.
} 
we can conclude that it is not anticompetitive for a SEP holder to license all of its SEPs in a single bundle for each standard.

But what about tying FRAND-committed patents to non-FRAND-committed patents? That requires a more complex framework and an extended model. Layne-Farrar and Salinger ${ }^{43}$ provide that extension, starting from the model developed in Gilbert and Katz ${ }^{44}$ but assuming that only one of the patents to be licensed is encumbered by a FRAND commitment. Taking all of the above discussions into account, we can interpret the inclusion of all the patents that a licensee might conceivably use - both FRAND-committed and not - as a form of commitment on the part of a patent owner not to behave opportunistically by suing for patent infringement on a non-FRAND-committed patent that the licensee of its FRAND-committed patents ends up infringing. The remaining question is then how such portfolio licenses affect FRAND licensing terms and conditions. The remainder of this chapter discusses the findings of the Layne-Farrar and Salinger (2016) study.

\section{Tying and Bundling with FRAND-Committed Patents}

What happens when we introduce a FRAND commitment on one, but not both, of the two patents in the simple two-patent model discussed above? To build up to the answer to that question, consider first an even simpler version of the model with only one patent that helps us to be more precise about what a FRAND commitment means. Assume that the manufacturer has a chance of inventing around the patent, investing $\mathrm{R}$ in a workaround that has a probability $\mathrm{p}(0 \leq \mathrm{p} \leq 1)$ of success. Under this framework, we can introduce the concept of a FRAND commitment by assuming that the patent holder has to set a license fee $\mathrm{L}$ before the manufacture makes any of its investments (either in $\mathrm{R}$ to invent around the patent or in $\mathrm{S}$ to commercialize the patented technology). ${ }^{45}$ In a standard setting context, the cost of a successful workaround $(\mathrm{R})$ can be interpreted as the cost of creating an alternative technology to define the standard, while the commercialization cost of $\mathrm{S}$ can be interpreted as the opportunity cost of not adopting an alternative.

The patent holder can consider three levels of royalties: the holdup amount, the net contributed value of the patented technology, or a rate that eliminates the licensee's incentive to invent around the patents. ${ }^{46}$ The first option sets $\mathrm{L}=\mathrm{B}$, the total value of the end product compliant with the standard.

\footnotetext{
${ }^{43}$ Layne-Farrar \& Salinger, supra note 3.

${ }^{44}$ Gilbert \& Katz, supra note 8.

${ }^{45}$ Note that we do not have to force to patent holder to actually set its license fee before the manufacturer makes its investment in S. It is enough to limit the patent holder to a license fee of $\mathrm{B}-\mathrm{S}$, which is the maximum amount it could have earned before the manufacturer's investment.

${ }^{46} \mathrm{We}$ show why this is the case in our formal model in Layne-Farrar \& Salinger, supra note 3. In essence, these three rates mark inflection points, such that charging something other than one of
} 
This is the holdup amount defined above, where the patent holder expropriates the full value of the manufacturer's sunk investment $S$. The second licensing fee option is $\mathrm{L}=\mathrm{B}-\mathrm{S}$, the maximum net value that the patented technology contributes to the end product, as explained above. The final licensing fee option is to set $\mathrm{L}=\mathrm{R} / \mathrm{p}$, the manufacturer's investment cost in working around the patented technology divided by its odds of success. This royalty rate is the maximum royalty that the patent holder can charge if it wants to prevent the manufacturer from attempting to work around its patents because this royalty rate reflects the payment at which the manufacturer is indifferent between trying to invent around the patent holder's patent and simply licensing that patent.

These three options define the patent holder's potential licensing fees, but we have not yet said which of those options is consistent with a FRAND commitment. That turns out to be a more complicated determination than one might suppose. Most obviously, setting $L=B$ is inconsistent with FRAND because that royalty fee takes advantage of holdup (it includes the licensee's investment $\mathrm{S}$ ) and it exceeds the contribution the patented technology makes to products compliant with the standard (which is capped at $\mathrm{B}-\mathrm{S}$ ) ${ }^{47}$ This leaves the familiar net value royalty of $\mathrm{B}-\mathrm{S}$ and the unfamiliar cost-based royalty $\mathrm{R} / \mathrm{p}$. The former rate, $\mathrm{L}=\mathrm{B}-\mathrm{S}$, is free of holdup and hence is consistent with FRAND. The latter rate, $L=R / p$, requires a closer look. As noted above, this is the rate that eliminates the manufacturer's incentive to attempt to replace the patent holder in defining the standard. If the patent holder sets its license fee $\mathrm{L}$ above $\mathrm{R} / \mathrm{p}$, the manufacturer will always have an incentive to attempt the workaround. ${ }^{48}$ The manufacturer may not always succeed (unless $\mathrm{p}=1$ ), but if the patent holder sets $\mathrm{L}$ at this level, it takes the chance that it will not define the standard and may not be able to license its patent at all. Thus, if the licensee wants to be certain that its patented technology will define the standard, it must prevent the manufacturer from investing in the workaround strategy. Setting $L=R / p$ achieves that goal and guarantees that the patent holder will earn some positive licensing fees. This explanation clarifies that $\mathrm{L}=\mathrm{R} / \mathrm{p}$ is also consistent with FRAND: it is a rate set with regard to competition to define the standard, it is not opportunistic and is free of holdup.

These findings provide an interesting policy dilemma for interpreting FRAND commitments. On the one hand, a FRAND-consistent license fee can be defined as any royalty that does not expropriate sunk, complementary investments. Such rates are non-opportunistic and free of holdup. $\mathrm{L}=\mathrm{B}-\mathrm{S}$ satisfies this criteria. On the other hand, we could also interpret FRAND as a commitment to set licensing terms

\section{(Footnote 46 continued)}

these rates would not result in the patent holder maximizing its licensing revenues within the constraints of particular parameter values.

${ }^{47}$ An alternative approach would be to assume that the manufacturer chooses $S$ only after it observes the outcome of its R\&D. Under that assumption, the IP owner would never be able to charge a license fee of $\mathrm{B}$ because that would incentivize the manufacturer to always try to work around the patent.

${ }^{48}$ See Layne-Farrar \& Salinger, supra note 3, at 1158-1159 (For the mathematical proof). 
and conditions that could be acceptable for SDO members during the standard development phase. This view of FRAND is consistent with the strand of the literature that interprets FRAND as requiring rates bounded by what the patent holder could charge at the time the standard is developed, reflecting any competition among technological solutions. ${ }^{49}$ For some parameter values, this conceptual standard limits the license fee to $L=R / p$. As we showed in our technical paper, $\mathrm{R} / \mathrm{p}<\mathrm{B}-\mathrm{S}$ is an insufficient criterion to guarantee that the patent holder will select $\mathrm{L}=\mathrm{R} / \mathrm{p}$ during the development of the standard. That is, even ex ante to a manufacturer's sunk costs, the SEP holder may sometimes view the chance of earning a relatively higher (but still non-opportunistic) royalty rate set at the net value $L=B-S$ as more attractive than the guaranteed royalty rate of $R / p$ that removes the risk the patents will not define the standard. Given how complicated that actual choice is for SEP holders, one might, as a practical matter, define FRAND as the lesser of the value-based and cost-based royalties. This combined rule would both preclude holdup and ensure that the patented technology could be chosen for the standard in some ex ante technology competition. ${ }^{50}$

Which of the two license fees is lower will, of course, depend on the real world values of $\mathrm{B}, \mathrm{S}, \mathrm{R}$ and $\mathrm{p}$. To see this, extend our earlier numeric example in which $\mathrm{B}=\$ 100$ and $\mathrm{S}=\$ 30$. Under these parameters, $\mathrm{L}=\mathrm{B}-\mathrm{S}$ will be $\$ 70$ (as before). Suppose that $R=\$ 36$ and $p=0.6$ (a $60 \%$ chance of successful workaround $R \& D$ ). In this case, the licensing option of $L=R / p$ would imply $L=\$ 36 / 0.6=\$ 60$, less than the $\mathrm{L}=\mathrm{B}-\mathrm{S}$ option. Thus, under a combined interpretation of FRAND, the patent holder would need to set $\mathrm{L}=\mathrm{R} / \mathrm{p}$ to comport with its FRAND commitment. If instead $\mathrm{R}=\$ 36$ but $\mathrm{p}=0.4$ (that is, the workaround $\mathrm{R} \& \mathrm{D}$ is riskier, with only a $40 \%$ chance of success), then the $\mathrm{R} / \mathrm{p}$ licensing option would imply $\mathrm{L}=\$ 90$, higher than the $\mathrm{L}=\mathrm{B}-\mathrm{S}$ option. In that case, to comport with FRAND the patent holder would need to charge $\mathrm{L}=\mathrm{B}-\mathrm{S}=\$ 70$. To implement the principle that FRAND means the minimum of $B-S$ and $R / p$, one needs to estimate all four parameters with sufficient precision to rely on them. In practice, some of the parameters may be easier to estimate than others and one might have a reliable estimate of $\mathrm{B}-\mathrm{S}$ or $\mathrm{R} / \mathrm{p}$, but not both. Under such circumstances, a practical policy would be to accept FRAND as either $\mathrm{L}=\mathrm{B}-\mathrm{S}$ or $\mathrm{L}=\mathrm{R} / \mathrm{p}$, whichever one can be measured reliably. Such a policy guide would offer greater flexibility for the patent owner than the minimum of $\mathrm{L}=\mathrm{B}-\mathrm{S}$ and $\mathrm{L}=\mathrm{R} / \mathrm{p}$, but would still offer protection to the patent user by limiting the ability of the patent owner to behave opportunistically.

\footnotetext{
${ }^{49}$ See, e.g., Daniel G. Swanson \& William J. Baumol Reasonable and nondiscriminatory (RAND) royalties,standards selection, and control of market power, 73 ANTITRUST L. J., at 1-58 (2005).

${ }^{50}$ The thought experiment of an ex ante technology auction is one approach to pinning down FRAND licensing, though it is generally viewed as a thought experiment rather than a practical solution to setting reasonable royalty rates. See, e.g., Swanson \& Baumol, id., and Damien Geradin et al., The Ex Ante Auction Model for the Control of Market Power in Standard Setting Organizations, EuR. COMPETITION J. (2008).
} 


\subsection{Patent Holders with Licensing Options Outside of the Standard-An Alternative Interpretation of $B$ and $S$}

Now that we have a definition of "FRAND" within our simple model, we can explore the implications of the standard setting context more fully. Thus far we have assumed that the patent holder can only earn a return on its investment in the patented technology if it licenses the single manufacturer. Within a standard setting context, this is analogous to assuming that the patented technology has no outside use and only has value if deployed in products compliant with the standard. In reality, pioneering technologies may have value to both a particular standard and to other products not compliant with the standard. This situation provides the patent holder with additional options and greater flexibility in setting its royalty rates. To explore this scenario, we need to move back to a model with two patents.

The two critical features giving rise to the need for cooperative standards are (1) competing technologies, each of which could serve as the standard (though perhaps with differing commercial success), and (2) network externalities. If a particular industry problem has only one technical solution, the firm that developed that solution will define a de facto standard-no cooperation among industry players is needed. As for condition (2), if there is no need for coordination on a single technical solution - that is, if it does not hinder efficient industry operations for each party to follow its own technology path - then there is again no need for a cooperative standard. It is only in the presence of network externalities, where the value of a technology for one user rises with the number of other users, that the selection of a common technical solution raises social welfare. We therefore extend the model to include two patent holders, competing to become the standard, and allow for three diverse manufacturers who place different values on the two competing technologies, which provides outside value to the patented technology not chosen to define the standard.

Assume that the two patent holders must set their licensing fees during the development of the standard, as a means to preclude any holdup licensing fees. Patent owner 2 has an outside licensing option, and can license its patented technology to a subset of manufacturers even if it does not win the standard competition. Patent owner 2 will set its license rate in the standard competition in light of what it expects to earn outside of the standard; it will never choose to set a rate in order to win the standard competition if that rate yields lower profits than it could earn through licensing the non-standard product maker. The outside option therefore puts bounds on how aggressively patent owner 2 will compete with patent owner 1 to win the standard. Patent owner 1 can therefore win the standard by setting its rate just below the amount it expects patent owner 2 will be willing to charge in the standard competition. In comparison, if the patent 2 technology has no value outside the standard, then there may be no floor to the rate patent holder 2 is willing to set during the competition for the standard. This scenario could lead to aggressive competition between the two patent owners, with low (or even 
near-zero) royalty rates resulting. ${ }^{51}$ In contrast, the stronger the outside option, the less flexible patent holder 2 will be during the standard competition.

The take away from this version of the model is that what defines an ex ante, no-hold-up royalty rate depends not only on the existence of competition among technologies to define the standard, but also on whether any of the technologies competing have value outside the standard. More generally, if the patent owners compete against each other to be included in multiple standards, licensing competition in practice might be either "soft" or "hard." In the real world, whenever competition over technologies involves patents with some outside value, competition is unlikely to lead the patent owners to set their rates at royalty free. ${ }^{52}$

\subsection{Licensing FRAND-Committed and Non-FRAND-Committed Patents Together}

We are finally ready to discuss the meaning of a FRAND commitment in relation to tying a FRAND-committed patent to a non-FRAND-committed patent. If two patents are complementary, why would it ever be the case that one has a FRAND commitment while the other does not? Oftentimes, the patent owner may have no choice: the owner is likely to be required to commit to FRAND if the patent is disclosed for use in a cooperative standard under development. In that instance, a portfolio license of all SEPs held for the standard will meet the criteria for the single rent theorem, as explained above, and bundling will pose no concerns. Other times, however, a particular patented technology may be included in an optional portion of a standard, which can render that patent non-essential. Another common occurrence is that the patented technology is not part of standard compliance at all, but still defines complementary and highly useful features for standard compliant products from a commercial point of view. In either of these latter scenarios, a patent complementary to an SEP may not be bound by a FRAND commitment, but both licensors and licensees may still be quite interested in including the patent in the license.

\footnotetext{
${ }^{51}$ Observe that the economic models that predict two patented technologies competing to define a standard will end up at zero licensing fees make the implicit assumptions that 1) the two patent holders have already sunk their R\&D investments in developing the patented technologies and thus are willing to earn a zero return on those investments (i.e., the licensees can practice reverse holdup and expropriate the patent $R \& D$ costs) and 2) neither rival can earn any return outside of the standard (the standard acts as a monopsonist). Moreover, it is important to understand that economists are referring to economic profits in these models; accounting profits may be positive while economic profits, which include opportunity costs, are zero.

${ }^{52}$ This is a separate point from those SDOs that voluntarily choose to follow a royalty free licensing policy. For these SDOs, whether competition across technologies exists or not is irrelevant for the royalty rate - it is always royalty free. Such SDOs constitute the minority.
} 
For simplicity, we return to the model with one patent holder, two patents ( 1 and 2 ), and one licensee/manufacturer. The two patents are complementary, but assume that the patent holder has made a FRAND commitment only on patent 1 and not on patent 2. The parameters are the same as above, with B defining the full value of the end product embodying the standard and S representing the manufacturer's sunk investment in commercializing the standard. Lastly, assume that the manufacturer can invest in potential workarounds for either or both of the patented technologies, with $R_{1}$ and $R_{2}$ representing the respective investment costs for each invent around effort, neither of which is guaranteed to be successful.

To form a baseline for considering patent bundling, first assume à la carte licensing only.

Suppose that the manufacturer successfully invents around patent 1 (displacing technology 1 as the standard) but fails to invent around technology 2. If the two patented technologies are complementary to one another, the manufacture will want a license to patent 2, which is not bound by any FRAND commitment. With licensing concluded after the manufacturer invests in $\mathrm{S}$, the patent holder can set its license fee for patent 2 at the full holdup value for the standard-compliant product, that is $\mathrm{L}_{2}=\mathrm{B}$. Suppose instead that the manufacturer fails to invent around either technology and needs a license to both patents 1 and 2 . In this case, even when the patent holder honors its FRAND commitment on patent 1, say by setting $\mathrm{L}_{1}=\mathrm{B}-\mathrm{S}$, with ex post licensing the patent holder can set the license fee for patent 2 at $\mathrm{L}_{2}=B-L_{1}$, again netting the full value $\mathrm{B}$ of the end product in the aggregate $\left(\mathrm{L}_{1}+\mathrm{L}_{2}\right)$. Either way, the patent holder can earn the holdup amount with the manufacturer losing all its sunk costs (in complementary inputs and any R\&D it performed).

It is the presence of the second patent without a FRAND commitment that allows the patent holder to increase its licensing revenues to the holdup amount ex post, even while honoring the FRAND commitment on patent 1 . If both patents are needed by the manufacturer and one is not bound by a FRAND commitment, then the manufacturer's need for access to the second patent enables the patent holder to practice holdup. This finding suggests that tying non-FRAND-committed patents with FRAND-committed ones could affect the portfolio royalty rate and could offer the patent holder a means to avoid its FRAND obligation. In our technical paper we established that the value-based license fee for patent 1 in the absence of a FRAND commitment on patent 2 is less than the value-based license fee for a bundle of patents 1 and 2 given FRAND commitments on both. As a result, to comply with its FRAND commitment the patent owner can either license patent 1 separately at a non-holdup rate or in a bundle with patent 2 at the same rate as for patent 1 alone. In other words, the patent holder cannot justify a higher license fee on the grounds that the portfolio rate would have been FRAND had both patents been bound by FRAND. To be true to the FRAND commitment, the portfolio license fee must include the non- FRAND patent "for free".

This result bears a closer look, as it might seem contradictory because it suggests that a particular royalty for a license to a bundle of two patents can be reasonable in some circumstances but not in others. But the reason for the difference in license 
fees for the exact same bundle of patents lies in the commitments encumbering those patents: whether a license fee to a bundle of patent 1 with patent 2 is consistent with FRAND depends on whether just one or both of the patents are bound by FRAND. Analyzing FRAND royalties entails in effect going back in time to imagine what terms the patent owner and manufacturer would have reached if they had contracted at an earlier date, before any sunk costs were made. Answering that question requires an understanding of what the expectations of both parties would have been at that earlier time. The presence or absence of a FRAND commitment on patent 2 affects the manufacturer's expectations and influences the meaning of a FRAND commitment on complementary patents like patent 1. Absent a FRAND commitment on patent 2 , the manufacturer would expect to need to invent around patent 2 in order to commercialize patent 1 and that expectation would limit what the manufacturer would be willing to pay for a license for patent 1 .

\section{Policy Implications}

The question explored in this chapter is whether a patent owner honors a FRAND commitment if it offers its FRAND-committed patent in a bundle with non-FRANDcommitted patents. At the most basic level, the answer is simple. Bundling is common throughout the industry and often reflects efficient market operations in response to product complexity rather than nefarious anticompetitive strategies. Thus, offering a bundle of FRAND-committed patents and non-FRAND-committed patents does not violate a FRAND commitment - as long as the patent owner either offers the FRAND-committed patent separately on FRAND terms or sets the rate for the bundle at a level that is FRAND compliant for just the FRAND-committed patents. If a separate offer of FRAND-committed patents is made, then the FRAND commitment places no additional restriction on the license fee the patent owner can seek for bundles that include the FRAND-committed patents. ${ }^{53}$ If a licensee views the bundled rate as somehow excessive or in violation of FRAND, that licensee can refuse to take the portfolio license and instead opt for the FRAND-committed patent license only.

\footnotetext{
${ }^{53}$ Strictly speaking, "mixed bundling" entails offering all the components of a bundle separately in addition to the bundle. However, a practical application of mixed bundling in patent licensing contexts would entail offering a license to the portfolio of FRAND-committed patents alone, offering a second license to the non-FRAND- committed patents (either as a portfolio or in rational subsets), and offering a third license with a bundle of the FRAND- and non-FRAND-committed patents together, rather than having to offer individual licenses of each FRAND-patent and each non-FRAND patent, for the product offering cost reasons we explain above. Yet another option would be for the patent holder to offer a license to the portfolio of FRAND-committed patents alone and offering a second license to the bundle of FRAND- and non-FRAND-committed patents, without offering a license to the non-FRAND-committed patents separately. As the non-FRAND-committed patents are not essential for any cooperative standard, the patent holder can choose to license them or not.
} 
Even if we restrict our attention to the pure bundling of FRAND-committed and non-FRAND-committed patents, with no separate license of FRAND-only patents allowed, we still cannot condemn bundled portfolio licensing. That being said, the opportunity to bundle other patents with FRAND-committed patents and claim credit for their value in determining FRAND terms for the bundle creates a clear risk of using bundling to circumvent the FRAND commitment. As a result, the inquiry must shift to the rates and terms charged for the bundle to assess whether or not the FRAND commitment has been violated. Here it is important to recall that FRAND does not imply a single, magic number, but rather encompasses a range of values fair and reasonable to both parties. Thus, even though a minority of SDOs require royalty-free licensing terms and conditions, a patent owner working within an SDO without such a rule would not violate its FRAND commitment if it decided to offer a royalty-free license to a bundle of patents that includes both FRANDcommitted and non-FRAND-committed patents. On the other end of the spectrum, the patent owner cannot account for the value of its non-FRAND-committed patents in determining a license fee for its FRAND-committed patents bundled into the license. The patent owner is within its rights to claim a stand-alone value for a non-FRAND-committed patent when that patent is licensed separately, but forcing the manufacturer to pay such a fee in order to access the FRAND-committed patent would amount to reneging on the FRAND commitment not to impose an opportunistic license fee. If the patent holder decides to offer its patents in bundled form only, then it needs to price that license as if it contains the FRAND-committed patents only. In short, a patent holder may include non-FRAND-committed patents for "free" when it chooses not to offer a separate FRAND-committed only license.

Refusing to offer a separate license to FRAND-committed patents cannot be inferred from simply observing that existing licenses cover bundled FRAND- and non-FRAND-committed patents. As explained in this chapter, the majority of licensees are likely to prefer bundled licenses, for freedom to operate and efficiency reasons. Particularly for older licenses, before the controversy over the potential for bundling to circumvent a FRAND commitment arose, it is probable that neither the patent holder nor the licensee ever mentioned (or even considered) a FRAND-only license, but rather focused all of their negotiations on the full set of patents of interest. This is not the same as refusing to grant a license to FRAND-committed patents only when asked to do so and instead reflects both parties' desire for the bundled option.

Moreover, the same economic logic that dictates that the patent holder cannot include the value of non-FRAND-committed patents within a license when determining a FRAND-consistent royalty fee also dictates that the licensee cannot demand a discount for the non-FRAND-committed patents included in a bundled license. Put differently, the licensee cannot assume that the bundled license price has been inflated above the rate the patent holder would have charged for a license to the FRAND-committed patents alone. As just noted, the patent holder may have included such non-FRAND-committed patents "for free", in which case no discount would be due. 
Finally, we observe that including additional non-FRAND-committed patents "for free" is not a mere theoretical possibility. Licensing terms for patent portfolios exhibit clear nonlinearities. A portfolio license price is not simply the sum of the individual patent values but instead reflects both economies of scale and scope. Thus, given the transaction costs involved in negotiating and enforcing license agreements, as well as the complementarities common across patents in a given technology space, licensors may well find it is in their best interests to add in related non-FRAND patents "for free".

Open Access This chapter is licensed under the terms of the Creative Commons Attribution 4.0 International License (http://creativecommons.org/licenses/by/4.0/), which permits use, sharing, adaptation, distribution and reproduction in any medium or format, as long as you give appropriate credit to the original author(s) and the source, provide a link to the Creative Commons license and indicate if changes were made.

The images or other third party material in this chapter are included in the chapter's Creative Commons license, unless indicated otherwise in a credit line to the material. If material is not included in the chapter's Creative Commons license and your intended use is not permitted by statutory regulation or exceeds the permitted use, you will need to obtain permission directly from the copyright holder.

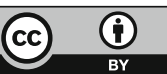

